\title{
Eco-management and audit scheme (EMAS) as an important element of the sustainable development policy on the example of public sector organizations
}

\author{
System ekozarządzania i audytu EMAS jako istotny element \\ kształtowania polityki zrównoważonego rozwoju na przykładzie \\ organizacji sektora publicznego
}

*Dr Janusz Myszczyszyn - Department of Economics, Faculty of Economics,

West Pomeranian University of Technology, Żołnierska 47 St., 71-210

Szczecin, Poland, e-mail: jmyszczyszyn@zut.edu.pl

Keywords: Eco-Management and Audit Scheme (EMAS), sustainable development, environmental protection, public sector Słowa kluczowe: system ekozarządzania i audytu (EMAS), rozwój zrównoważony, ochrona środowiska, sektor publiczny

\section{Abstract}

The necessity to protect natural resources in accordance with the idea of sustainable development is an indisputable issue. Not only the industrial sector organizations, but those of the public sector as well must join this process. The Eco-Management and Audit Scheme can play an important role in this respect. 3.7 thousand organizations have already registered in the EU EMAS register, including, unfortunately, only 71 from Poland, of which almost $40 \%$ from the public sector. The author tries to set out the benefits, resulting for the public sector organizations from the implementation of the scheme, but also the barriers and weaknesses of the system, which makes it not very popular in Poland. The results of the author's own research carried out in 2016 among representatives of EMAS system, inter alia, of public sector organizations in Poland were used for this purpose.

C C IOŚ-PIB

\section{INTRODUCTION}

The balance between the economic growth and the need to protect the environment and preserve non-renewable natural resources for future generations has become an important element of contemporary economic policies.

We can see more and more initiatives: international and global, including those under the auspices of the United Nations, whose aim is to ensure sustainable development. The area of environmental protection is joined not only by developed countries but also by developing countries. An example would be the 2015 Paris conference at which the international community has taken steps to reduce $\mathrm{CO}_{2}$ emissions. On $25^{\text {th }}$ September 2015, the General Assembly of the United Nations passed the Transforming Our World resolution: Agenda for Sustainable Development 2030 [Rezolucja 2015].

The Treaty of the European Communities, in Article 3 set out: The Union shall establish an internal market. It shall work for the sustainable development of Europe, based on balanced economic growth and price stability, a highly competitive social

\section{Streszczenie}

Konieczność ochrony zasobów naturalnych zgodnie z ideą rozwoju zrównoważonego jest kwestią bezdyskusyjną. W ten proces muszą włączyć się nie tylko organizacje sektora przemysłowego, ale także organizacje sektora publicznego. System ekozarządzania i audytu może odegrać w tym względzie ważną rolę. W unijnym rejestrze EMAS zarejestrowanych jest już 3,7 tys. organizacji, to jednak zaledwie 71 z Polski, w tym niemal $40 \%$ z sektora publicznego. Autor próbuje ocenić, jakie korzyści wynikają z implementacji systemu dla samej organizacji sektora publicznego, ale także bariery i słabości sytemu, które sprawiają, że EMAS jest w Polsce ciągle mało popularny. W tym celu posłużono się wynikami badań własnych przeprowadzonych w $2016 \mathrm{r}$. wśród pełnomocników systemu EMAS m.in. wśród organizacji sektora publicznego w Polsce. market economy, aiming at full employment and social progress, and a high level of protection and improvement of the environment quality. It shall promote scientific and technological progress [Traktat 2012].

In order to support sustainable development as early as already in 1993, the EU Parliament and Council adopted the first EMAS regulation, allowing organizations their free participation in the Community Eco-ManagementandAudit[Myszczyszyn 2010].After the 2001 changes in the Regulation, non-industrial organizations can also join the system, which explains the author's interest in public sector organizations. Public sector organizations may play an important role in the future in the propagation of EMAS system in Poland and EMAS system has a chance to exert an important impact on promoting the sustainable development aspects.

While preparing the article, the author assumed the following objectives:

to analyse the statistics on the implementation of the EMAS system in public sector organizations; 
- to see that the public sector entities can also have a significant influence on the environment and on private sector organizations, and promote sustainable development;

- to indicate the impact of environmental systems on a continuous increase in the awareness of sustainable development in our country;

- $\quad$ to produce major benefits and barriers that accompany the implementation of EMAS.

\section{RESEARCH METHOD}

To review the research hypothesis posed and research objectives, the author used:

a) secondary materials, which include: the statistics available under the Community EMAS register, the register kept by the General Directorate for Environmental Protection, Environmental declarations of EMAS registered organizations and sites, literature on the subject matter;

b) primary materials - results of the author's own research conducted amongst EMAS registered organizations. The questionnaire survey was conducted between May and December 2016 and related to public sector organizations.

The author has divided 71 organizations registered in Poland into two groups: public sector and private sector organizations. The questionnaire designed and drawn up by the author was sent to the representatives of the EMAS environmental management system, identified in the environmental statements. The questionnaire included 14 questions on EMAS, including 4 openended questions, 10 closed questions ( 3 alternative questions, 3 disjunctive questions, 4 conjunctive questions) and 4 semi-open questions.

Thirty-two organizations, including 19 belonging to the public sector and 13 to the private sector, agreed to participate in the study. The subject of this article are the results for the 19 public sector organizations.

\section{RESULTS AND DISCUSSION}

The participation in EMAS scheme is free and open to all kinds of organizations. It is assumed that EMAS shall be made available to all organizations, in and outside the Community, whose activities have an impact on the environment. EMAS shall provide these organizations with the measures to manage that impact and to improve their overall environmental performance [Rozporządzenie 2009]. The first organization outside the industrial sector, which joined the EMAS was the City of Varese Ligure in Italy [EMAS Newsletter 2006].

With regard to the ISO 14001 environmental management system, EMAS adds four elements:

- constant improvement of pro-environmental action by the necessity to renew the registration, to update the environmental statement and a continuous setting out of new environmental objectives;

- compliance with the legislation on the environmental protection guaranteed by the participation of government authorities in the system; universal access of public opinion through open publications of environmental statements, environmental reports;

involvement of organizations' employees and management [Myszczyszyn, 2010].

Organizations, intending to be EMAS registered, among other things, must conduct an environmental review, implement an effective environmental management system, carry out an internal environmental audit, prepare an environmental statement, describing both the environmental management system and the environmental performance results [Ustawa 2011, Rozporządzenie 2012].

As of $13^{\text {th }}$ October 2016, the EU EMAS register included 3,701 registered organizations, which are represented by 11,230 sites. In Poland, the system registered 71 organizations and 357 sites $(1.92 \%$ and $3.18 \%$, respectively). There are only 1.8 organizations per 1 million residents [Sustainable 2015]. This constitutes a well visible improvement compared to the 17 organizations registered by the end of April 2009, but still, there is an enormous gap between us and Germany, Italy and Spain [Myszczyszyn 2010]. A list of organizations, operating in Poland and those EMAS registered by sections of national economy is shown below (Fig. 1).

Section E organizations prevail (remediation and other services related to waste management) (21 organizations)), together with those of section $\mathrm{O}$ (public administration and defence, compulsory social security (19 organizations)) and section $\mathrm{C}$ of industrial manufacturing (15 organizations).

No organizations of the following sections have been registered: A - agriculture, shooting and forestry, G- wholesale trade, except for motor vehicles and $\mathrm{P}$ - education.

The public sector organizations tested by the author represented sections: O (14 organizations), E (3 organizations), K (1 organization) and $\mathrm{Q}$ (1 organization).

The author has conducted its own survey of 19 public sector organizations, listing the main environmental objectives laid down in the environmental statements of the public sector

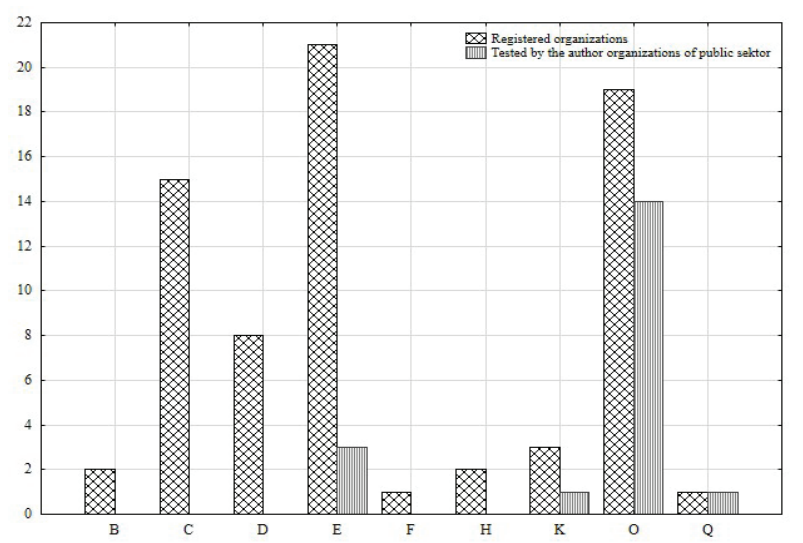

Figure 1. Organisations registered in the EMAS in Poland by sections of national economy (11.10.2016) and tested by author public organizations (10.12.2016). Source: Own calculations based on: data www.emas.gov.pl (15.11.2016) and the author's own research. 
organizations, which, among other things, emphasized the environmental mission. This mission is particularly important in view of the promoting practices in the field of sustainable public procurement, encouraging to create and promote effective public and public-private partnership, as well as, that involving civil society, built on experience and sourcing strategies in partnership [Rezolucja 2015].

The public sector organizations registered in EMAS and under the author's survey focused, among other things, on:

- $\quad$ rational use of water resources and water, including the wastewater management;

- $\quad$ air protection and noise reduction;

- $\quad$ working place environment protection;

- $\quad$ ensuring effective and stable protection of reserves and monuments of nature;

- $\quad$ prevention of hazards to the environment, resulting from the activities of the environment users;

- $\quad$ exerting influence on society, with reference to the need to protect endangered species of animals and plants;

- $\quad$ shaping appropriate approach of employees aimed at reducing the consumption of electricity, water and paper;

- $\quad$ ensuring access to the environmental information to public;

- continuous improvement of environmental performance contained in environmental statements.

An important goal is the active participation of employees in the implementation of specific tasks related to environmental protection. This is manifested through participation in training, certification, preparation of environmental statements, the current functioning of the company, as well as improved working conditions (e.g., by reducing hazardous factors such as noise)

The respondent public sector organizations indicated the following main benefits of the introduction of EMAS:

- increased awareness of the need for action in the field of environmental protection (15 replies);

- continuous improvement, and by the same, an impact on the sustainable development of the country and the world (14 replies);

- $\quad$ other benefits include: increased awareness of employees on the impact they may have on the environment, minimizing consumption of resources, among other things, of paper (printing and copying), water, electricity, heat etc., the impact on other organizations, of which suppliers, and customers (applicants included). EMAS scheme representatives, who responding to the questionnaire, could not see the direct economic and financial benefits, arising from the introduction of EMAS, improvement in employees working conditions and increased competitiveness.

Considering the data collected in the survey, the author has reasons to assume that the implementation of environmental management systems, including the EMAS scheme, increases the awareness of organizations, institutions, their management and employees, as well as, of the society regarding the care that should be taken of the natural environment, so as to contribute to the promotion of the idea of sustainable development. [Myszczyszyn 2009]. Additionally, in their construction, the environmental management systems use the achievements in the field of quality management, manifested only in the continuous improvement of the system.

Respondents indicated that despite measurable benefits, the EMAS scheme also has weaknesses which include:

- $\quad$ the necessity to set out, document and verify subsequent environmental objectives, which means extra costs and in the case of large environmental goals, it may be difficult to put them into life;

the need to develop regular environmental reports, which requires the involvement of staff and management and may interfere with the ongoing activities of the organization;

- laying down of further environmental goals, which in the case of public sector organizations, in the absence of a comprehensive pro-ecological policy of the state, can become a challenge;

- $\quad$ no measurable effects in terms of limiting the additional inspections related to environmental protection on behalf of state authorities;

no amenities with respect to grants for direct investments into environmental protection;

- no tax relief other benefits, such as, in tender procedures and applications for EU funds;

- poor promotion of the EMAS logo, in many cases unknown by other organizations and citizens.

When asked about the main reasons for the implementation of EMAS in their organizations, the respondents indicated:

- needed continuous improvement of their environmental performance; the achievement of the next stage was included in this sphere, as they had in ISO 14001 system earlier; increased prestige of the organization and the promotion of environmental protection in the external environment included;

- increased involvement of employees in achieving environmental objectives;

- $\quad$ the promotion of idea of green management office;

- $\quad$ the instruction of superior authority.

Taking into account the above analysis, the author positively concludes that the implementation of environmental management systems, including the EMAS scheme, increases the awareness of organizations, institutions, their management and employees, as well as, the society that the care about environment is needed to contribute to the promotion and implementation of the idea of sustainable development.

\section{CONCLUSIONS}

The intention to ensure sustainable economic growth and to avoid turbulence and economic crises is one of the most important challenges of the modern world. However, at the present phase of civilization development, such an attitude is insufficient. Man can no longer ignore the sphere of environmental protection, and then comes the need to implement the idea of sustainable development. 
Despite the obvious benefits, it requires additional costs being incurred, which can be high (apart from the registration and certification) to achieve environmental objectives. The assumptions of the EMAS scheme of continuous improvement and verification of targets, along with laying down new ones, create difficulties for the organizations already registered and a barrier to the potentially interested new candidates.

As suggested by numerous authors, the implementation of EMAS has an impact on the external and internal benefits gained, on suppliers and customers included [Strachan et al. 1997, Hillary 2004, White and Lomax 2010, White et al. 2014]. However, the cost of investments in the area of environment may sometimes exceed the short term revenues, but the long term financial benefits, the environmental ones included, can be significant.

Man, together with his business activities, keeps interfering with the natural environment and creates a permanent threat for plants, animals and microorganisms, surrounding him, along with the atmosphere. By doing this, he worsens his own life and environment. As a consequence of the above, the implementation of the EMAS Eco-Management and Audit Scheme is a chance to put into life the sustainable development guidelines. This can also be a chance for the organizations, which already have ISO 14001 environment management system, to further improve their environmental actions within EMAS.

\section{REFERENCES}

EMAS Newsletter, No 2/Maj 2006. The European EcoManagement and Audit Scheme. https://oldsite.iema.net/ system/files/emas20newsletter20200620issue2022020beyond20320years.pdf.

GECEVSKA V., DONEV V., POLENAKOVIK R. 2016. A review of environmental tools towards sustainable development, Annals of Faculty Engineering Hunedoara - International Journal of Engineering, Tome XIV, 1 Fascicule [February]: 147-152.

HILLARY R. 2004. Environmental management systems and the smaller enterprise. Journal of Cleaner Production 12: 561569.

MYSZCZYSZYN J. 2009. Rola wspólnotowego systemu ekozarządzania i audytu (EMAS) w promowaniu zrównoważonego rozwoju w Polsce, Acta Scientiarum Polonorum (Oeconomia) 8, 4: 127-138.

MYSZCZYSZYN J. 2010. Polskie doświadczenia w implementacji wspólnotowego systemu ekozarządzania i audytu w świetle najnowszego rozporządzenia EMAS III, Ochrona Środowiska i Zasobów Naturalnych nr 44: 44-50.

MYSZCZYSZYNJ. 2010. Próba oceny korzyścii barier związanych z implementacją Wspólnotowego Systemu Ekozarządzania i Audytu (EMAS), Folia Pomeranae Universitatis Technologiae Stetinensis, Oeconomica 277, 58: 57-70.

Rezolucja przyjęta przez Zgromadzenie Ogólne w dniu 25 września 2015 r., 70/1. Przekształcamy nasz świat: Agenda na rzecz zrównoważonego rozwoju 2030 (Transforming our world: the $\mathbf{2 0 3 0}$ Agenda for Sustainable Development) (dostęp: https://www.mos.gov.pl/fileadmin/ user_upload/mos/srodowisko/miedzynarodowe_aspekty_
Viewed from the perspective of a few years back, the involvement and participation of key organizations in the system responsible for the generation and implementation of environment protection policy, such as the Ministry of Environment and Regional Directorates of Environment Protection, shall be evaluated positively.

The involvement of public entities is a signal to other organizations to try to make their employees and society aware that each of them independently, by the form of ownership and the character of their businesses, can have an impact on the pro-ecological behaviour. The best example of a positive impact on society is the EMAS scheme being implemented by the City of Varese Ligure, already mentioned in this paper. The engagement of public organizations gives the impression that in the future, they may involve a greater participation of SMEs, farmers and food economy environment, manufacturers, and above all, the education section into the EMAS scheme and pro-ecological action.

The issue of society education still remains a sine qua non matter, which needs drawing up a respective syllabus, preparation of mass media, the Internet, and an active participation of schools, universities and public organizations so as to promote pro-ecological conduct. Well-spread use of respective tools to evaluate environmental aspects within the idea of sustained development is equally important [Gecevska et al. 2016].

zrownowazonego_rozwoju/Polska_wersja_jezykowa_ dokumentu_Przeksztalcamy_nasz_swiat._Agenda_na_ rzecz_zrownowazonego_rozwoju_2030..pdf).

Rozporządzenie Ministra Środowiska z dnia 1 lutego 2012 r. w sprawie wzoru wniosku o rejestrację organizacji w rejestrze EMAS. Dz.U. 2012 nr 0 poz. 166.

Rozporządzenie Ministra Środowiska z dnia 23 marca 2012 r. w sprawie współczynników różnicujących wysokość opłaty rejestracyjnej za wpis do rejestru organizacji zarejestrowanych w krajowym systemie ekozarządzania i audytu (EMAS). Dz.U. 2012 nr 0 poz. 341.

Rozporządzenie Parlamentu Europejskiego i Rady (WE) $\mathrm{Nr}$ 1221/2009 z dnia 25 listopada 2009 r. w sprawie dobrowolnego udziału organizacji w systemie ekozarządzania i audytu we Wspólnocie (EMAS). Dz.U. Unii Europejskiej L 342 z 22.12.2009.

STRACHAN P., HAQUE M., MCCULLOCH A., MOXEN J. 1997. The Eco-Management and Audit Scheme: Recent experiences of UK participating organizations, European Environment, Vol. 7, 1: 25-33.

Sustainable development in the European Union 2015. 2015 monitoring report of the EU Sustainable Development Strategy, Eurostat, Luxembourg: Publications Office of the European Union.

Traktat o Unii Europejskiej (wersja skonsolidowana). Dz.U. C 326 z 26.10.2012.

Ustawa $z$ dnia 15 lipca 2011 r. o krajowym systemie ekozarządzania i audytu (EMAS). Dz.U. 2011 nr 178 poz. 1060. 
WHITE G., LOMAX M., PARRY G. 2014. The implementation of an environmental management system in the not-for-profit sector, An International Journal, 21, 4: 509-526.

WHITE G., LOMAX M. 2010. Environmental Management Systems: costs, benefits and an activity theory approach to understanding their knowledge-generating capabilities. The Environmentalist 100: 12-16. 